$$
\text { الثأشـير الهرضى الوظيفى لســـ د يستور البلح }
$$

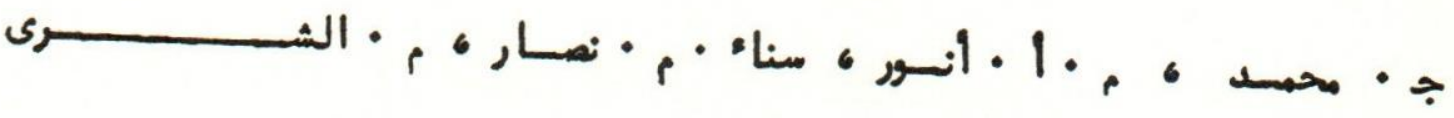

$$
\begin{aligned}
& \text { ادى حتــن ســم ديــور البلع فى الفئرا الى اتساع زئاد ةالدم اللارد }
\end{aligned}
$$

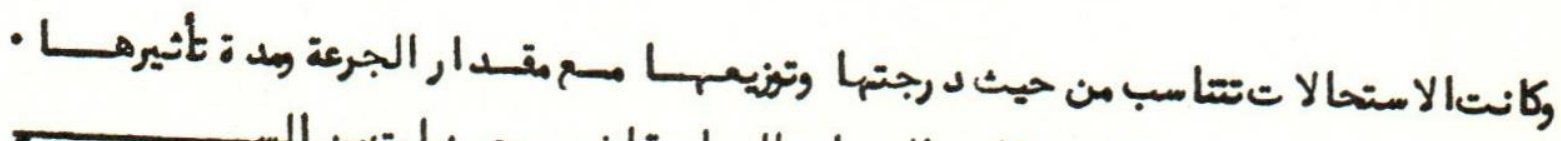

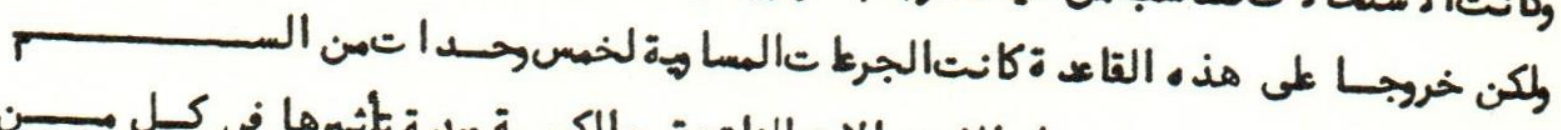

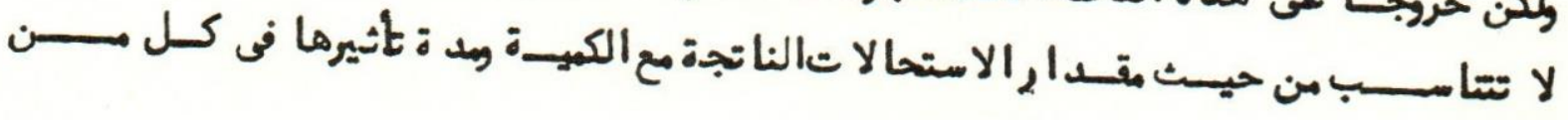

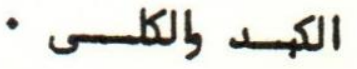

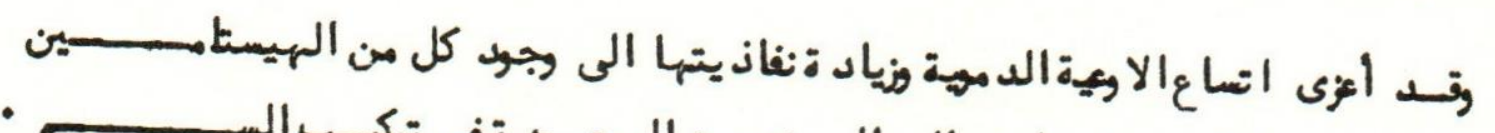

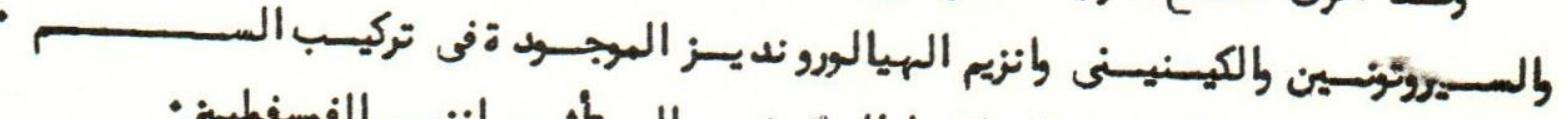

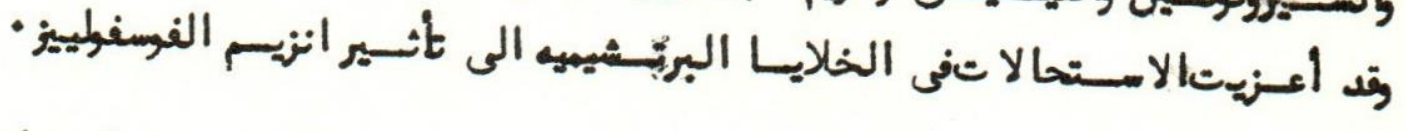

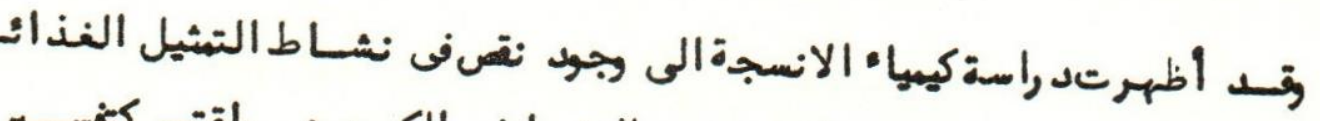

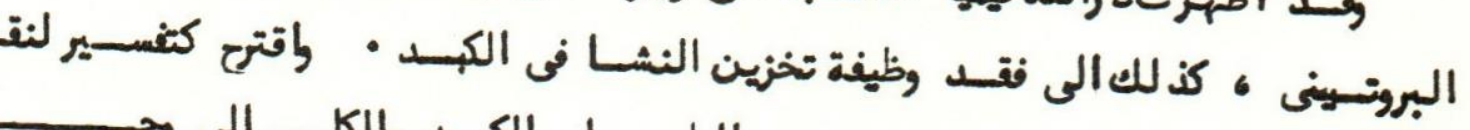

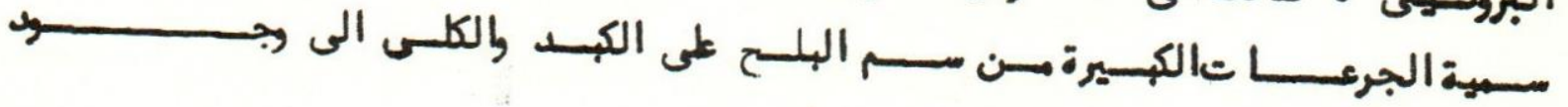

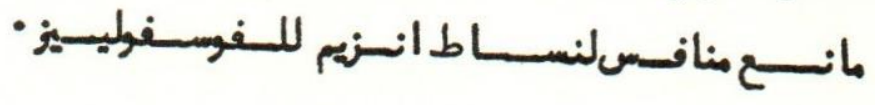


Assiut University

Faculty of Medicine Dept. of Physiology,

Head of Dept. Prof. Dr. Hamed Y.

BIOLOGICAI STUDIES ON THE VENOM OF DATS WASP

(VESPA ORIENTAIS)

III THE PATHOPHYSIOLOGICAL EFPECT ON THE LIVER AND KIDNEY (With 6 Figures)

\author{
By \\ MOHAMED, M.G., ANWAR, I.M., ${ }^{\text {I }}$ SANAA M. NASSAR \\ and EL-SHERRY, M.I. ${ }^{\text {xF }}$ \\ (Received at $1 / 11 / 1977$ )
}

\title{
SUMMARY
}

Injection of wasp venom in rats resulted in hyperaemia and increased vascular permeability in both liver and kidney. The parenchymatous cells of both organs manifested granular proteinous dystrophy and hydropic proteinous dystrophy up to focal lyses. The dystrophic changes were proportionated in distribution and severity according to the dose and time of application. An exception was with five stings dosage where the liver and kidney damage was neither proportionated th the magnititude of the dose nor with the prolonged time of application.

The vascular hyperaemia and permeability were related to the histamine, serotonin, kinins and hyalouronidase components of the venom. The parenchymal cell damage was related to the phospholipase A enzyme content of the venom. The histochemistry demonestrated proteinous metabolie hypoactivation and loss of the liver glycogenesis. A competive phospholipase inhibition was suggested for the decreased toxicity of higher doses.

Z Zoology Dept. Faculty of science, Assiut University. Ix Pathology Dept. Faculty of Vet. Med. Assiut Unirersity.

Assiut Vet Med. J. Vol. 4 №. $8,1977$. 


\section{MOHAMED et al.}

\section{$-56-$}

\section{INTRODUCTION}

Plenty of works have been done to investigate the natture and effects of wasp venom. Chemically, HABERMANN, and REIZ, 1965; reported that wasp venom centains histamine, serotonin, kinins, and the enzymes phgspholipase $\Delta$ and phospholipase B and the hyalouronidase. HANED et al. (1973) demonestrated that Egyption wasp venom contains $1.85 \mathrm{mg}$ serotonin and free amino acids. Physiologically, MOHAMED et al. (1972) studied the effect of the venom on the anaethetised dogs. The venom resulted in a significant drop in blood pressure and a significant decrease in urine flow and a significant acceleration of respiration with no apparent change on the E. C. G. Phenergan blocked its action while allercur was only capable of blocking the lower doses of the venom. HAIMED and MOHAIED (1975) studied the effect of the venom on the oxygen consumption by isolated tissue slices. Contradictive results were obtained. The venom produced a significent decrease in oxygen consumption by brain slices and significant increase in oxgen consumption by kidney tissue. The oxygen consumption by jujenal slices was increased only with two stings dose.

This contradictory physiological properties of the wasp venom specially with higher doses lead us to study structural changes of the tissue histopathologically and to correlate them with the functional changes of the tissue histochemically and physiologically in order to explain the actual way of tissue dammage by venom.

\section{MATERIALS AND METHODS}

Date wasps were collected from their nests during the date season from Assiut Governate. The entire venom apparatus was removed, cleaned and stored in deep freeze for use. Assiut Vet. Med. J. Vol. 4 №. $8,1977$. 


\section{PATHOPHYSIOLOGY OF WASP VENOM}

\section{- $57 \quad-$}

A definite number of the stings wetted with distilled water were ground in a small mortar. Additional amount of distilled water was added and the entire mixture was centrifuged. The supernatent fluid was collected and the volume was adjusted so that each ml contains the venom extract of 10 stings. Albino rats were divided into three groups (each of 9 animals). The venom prepared was injected intraperitoneally in the dose of one sting in the first group, two stings in the second group and five stings in the third group of rats. These rats from each group were decapitated 15,30 and $60 \mathrm{~min}$. after venom injection. Specimens from the liver and kidney of each rat were fixed in neutral buffer formalin and carnoy fixatives. The materials were embeded in paraffin. Section of seven micron thickness were stained by: Hematoxyline and eosin, methyl green pyroinin, fulgen reaction, P. A. S. and Toludin blue. Control groups of nine rats injected with distilled water were used for comparison with the venom injected rats.

\section{RESULTS}

The pathophysiological effect on the liver:

15 min. aplication of one sting of the poison lead to a limited damage of the liver cell inform of granular proteinous dystrophy. The damage was clear and limited in the ceIls around the portal triad; center of the vascular lobule or the periphary of the anatomic lobule; as they are the first cells supplied by the blood borne toxins; Vasodilatation was clear in the central and portal veins with mucoid oedema of their wall, while the sinusoidal hyperaemia was slight. There was also dilatation of the periportal lymphatic space of male.

The desoxyribonucleic acid content of the nuclei was lowered, on account of the decrease in the number of dark Assiut Vet. Med. J. Vol. 4 №. $8,1977$. 


\section{MOHAMED et al.}

\section{$-58$}

nuclei of the relatively highly active liver cells, in the zone of dystrophy and moderate staining of the other nuclei.

The swollen dystrophied cells lost the pyrininophilia totally or it was in a few granules in a ring around the nuclei.

The PAS reaction demonstrated that few lobules contained small amount of glycogen granules in the periphary of the ceIl cytoplasm. 'l'he rest of the lobules were free.

Application of one sting for $30 \mathrm{~min}$. resulted in more severe cell damage manifested in form of diffuse granular proteinous dystrophy and foci of cell lysis near by or related to portal triad (Fig. I). Also there were few cell foci of necrobiosis. The degree of hyperaemia, was more or less the same. The lympharic dilation increased to involve the pericellular spaces of Disse.

The desoxyribonucleic acid content was lowered to half its normal content on account of the decrease of the dark nuclei diffusely and focally and the necrobiosis and lysis of the nuclei. Pyrininophilia was decreased to half its normal centent. The liver was totally free of glycogen.

$60 \mathrm{~min}$. application led to a severe Liver cell damage as more or less diffuse early hydropic proteinous dystrophy with foci of cell lysis.

The decrease in the desoxyribonucleic and pyrininophilia corresponded to the degree of cell dammage.

only sporodic cells in some lobules and the peripheral zone of the others contianed sume PAS positive granules while the rest of parenchyma was free.

The cell dammage was corresponding to the increase of the dosage. 2 stings application for $15 \mathrm{~min}$. caused diffuse Assiut Vet. Med. J. Vol. 4 №. $8,1917$. 


\section{PATHOPHYSIOLOGY OF WASP VENOM}

\section{- 59}

granular proteinous dystrophy with more cells showing necrobiosis. $30 \mathrm{~min}$. application of 2 stings initiated diffuse hydropic proteinous dystrophy of some lobules while the rest of the lobules suffered granular proteinous dystrophy. By 60 Min. application, the hydropic proteinous dystrophy was adraneed, severe and diffuse (Fig. 2).

The decrease of desoxyribonucleic acid and pyrininophilia was correspondant to the severity of damage.

The glycogen content with 15 and 30 min. application was in form of few PAS positive granules present in the cytoplasm of sporadic liver cells (Fig. 3). Within $60 \mathrm{~min}$. application the liver was totally free of glycogen.

The severity of liver damage was neither proportionated with the magnititude of 5 stings dosage, nor with the prolonged time of application.

b stings application for 15 min. gave diffuse grenular proteinous dystrophy but of slighter degree. The number of necrobiotic cells were fewer. The condition was more or less the same with 30 min. application. In 60 min. application only zones of light swelling of liver cells appeared in addition. (Fig. 4).

The desoxyribonucleic acid and pyrininophilia was correspondant to the amount of darrage.

The glycogen was present in cells around the central veins of few lobules.

The pathophysiological effect on the kidney:

With one sting of the poison introduced for $15 \mathrm{~min}$. only individual nephrons demonstrated granular protelnous dystrophy or mild hydropic dystrophy which was epecially pronounced

Assiut Vet. Med. J. Vol. 4 №. 8, 1977. 


\section{MOHAMED et $\underline{a .}$.}

\section{- $60-$}

in the proximal convoluted tubules. The distal convoluted tubules demonstrated drivatives of haemoglobin pigment in form of fine granules in the cytoplasm and lumen.

In $30 \mathrm{~min}$. application nearly all the nephrons manifested cloudly swelling (Fig. 5). 60 min. application resulted in severe degree of hydropic dystrophy of some nephrons on the back ground of diffuse cloudy swelling of the parenchyma.

2 stings application for $16 \mathrm{~min}$. resulted in a magnitude of dammage equal to that of one sting spplication for $60 \mathrm{~min}$. The histopathological picture was the same beside abundant haemoglobin corpusles and casts.

With 2 stings application for $30 \mathrm{~min}$. the number of nephrons suffering hydropic degeneration became more while in 60 min. application the hydropic degeneration was diffuse. (Fig. 6).

Five stings application for $15 \mathrm{~min}$. only resulted in slight damage. Few nephrons suffered cloudy swelling, the rest of parenchyma was more less normal.

5 stings application for $30 \mathrm{~min}$. intiated diffuse cloudy swelling with hydropic degeneration of few nephrons.

60 min. application of 5 stings caused only mild degree of diffuse proteinous dystrophy.

Normal control kidneys and the kidneys under different doses and variable duration were free of glycogen. Also no pyrininophilia was observed. The ammount of desoxyribonucleic acid decreased and was proportional to the amount of damage.

\section{DISCUSSION}

Hyperaemia of the blood vessel in both liver and kidney was evident with the application of the smallest dose for the Assiut Vet. Med. J. Vol. 4 No. , 1977. 


\section{PATHOPHYSIOLOGY OF WASP VENOM}

\section{$-61-$}

shorter time ( $15 \mathrm{sec}$ ). Increased capillary permeability was manifested by oedema of the perisinusoidal space of Disse and the space of firle. The wasp venom contains mainly active principales that alter the vascular permeability of the tissue. HAIDD et all. (IY73) found that the wasp venom contains $38.5 \mathrm{mg}$ nistamine and $1.85 \mathrm{mg}$ serotonin for each gram of the poison. JAOUES and SCHACHPER, (1954) discovered kinins in wasp venom. Histamin is the main factor controling permeability physiolosically and in an inflammation. Serotonin the main intiator also seconderly increases permeability. WAITER and ESKAHI (1965) stated that kinins are cabable of causing vasodilation and increase the capillary permeability. They suggested that they are responsible for the important prolonged second phase of increased vascular permeability in an ind lammation. In addition to histamine, serotonn and kinins present in wasp venom, JAQUES, 1955 established the presence of hyalouronidase enzyme with its characteristic effect on the vascular and connective issue permeability. The presence of hyalouronidase explains the occurrence of mucoid oedema in the wall of the central and portal veins.

The action of wasp venom on the parenchymatous cells of the liver and kidney was dystrophic changes which varies in distribution and severity according to the dose and the time of application. The damage varied from regional granular protein dystophy to diffuse and diffuse hydropic dystrophy. In the pathogenesis of the granular proteinous dystrophy and hydropic distrophy, hypoxia lead to dissoclation of lipoprotion complex of the metochondria and of the endoplasmic reticulum. As it passes to hydropic changes there is increase accumulation of fluid in the cytoplasm which is partely due to osmosis and mainly due to large increase in the cell wall permeability. DAVYDOVSKY, (ly71). This alteration explained Assıut Vet. Hed. J. Vol. 4 No․ $8,1977$. 


\section{MOHAMED et al.}

\section{- $62-$}

only the back ground of the biological action of the phospholipase A content of the wasp venom. HABERMANN and REIZ,(1965) found that phospholipase constitute $12 \%$ of the dry venom mass. Phospholipase A splits one fatty acid from phosphatidyl compounds thus leaving monoachylophosphatid as a lysocompound. These lyso-compound causes universal membrane damage.

It causes increased permeability of the muscie cells (HEYDENREICH, 1957), perfused organs (KELIAWAY and TRETHEWIE, 1940) and brain (GAUTRELET and CORTAGGIANT, 193y). Phospholipase inactivates the respiratory enzymes either directly or through the liberation of lysolecithins and its action on the mitochondria where lipids are intergal parts ( HABERMANN and ZPURER, 1971 ). Phospholipase directly inhibits oxidative phospherylation ( HABERMANN, 1954 ). Thus phospholipase A is the compenent responsible for the intiation of granular proteinous and hydropic dystrophy of the liver and kidney cells.

The presence of haemoglobin pigments in the kidney tubules was due to the haemolytic effect of the venom. This can be also related to the action of phospholipase A (HAVERMANN , 1y54). Phospholipase A acts on plasma lecithines and Liberates lysoicitmins which will increase the permeability of erythrocytic membrane leading to swelling and haemolysis.

The severity of the liver and kidney damege was neither proportionated with the magnitude of 5 stings dosage nor with prolonged time of application for this dose. Similar results were obtained by HAMED and MOHAMED (1975) where the venom increased the oxygen consumption of jujenal slices only when the dose of 2 stings is applied. Five stings have no influence. They explained this contradictory results by the complex composition and the different components present in this venom. The histopathological results demonestrated that

Assiut Vet. Med. J. Vol. 4 №. $8,1977$. 


\section{PATHOPHYSIOLOGY OF WASP VENOM}

\section{- $63-$}

the damaging effect on the liver and kidney cells was mainly due to puospholipase A content of the venom. It is suggested that there is a competive enzyme inhibition with the higher doses either from the other venom components or from products of their action. Further work is suggested for isolation and identification of this component. Steroisomers may be used for competive inhibition of the enzyme as antidote.

The desoxyribonuclic acid content of the nuclei and the ribonucleic acid content (pyrininophilia) were decreased corespondingly to the degree of cell damage in both liver and kidney. Wasp venom with its content phospholipase A not only caused structural changes in the parenchymatous cell but also proteinous metabolic hypoactiveation which was completely arrested in the zone of focal liver cells lysis. Abscence of glycogen in the liver indicated the loss of important liver

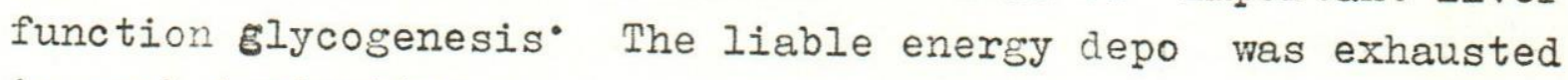
in such toxication.

\section{REFERENCES}

Davydovsky, I. (1971): General human pathology. Mir publishers Moscow. $67-70$.

Gautrelet, J. and Corteggiani, E. (1939): Étude comparative de la liberation de l'acetylcholine due tissue cerebral in vitro par les venins de cobra ou de vipra aspis, la lysocithine et la soponine. Copt. Red. Soo. Biol. 131, 951 - 954.

Habermann, E (1954): Zur pharmakologie de Heltitin, Arch. Exper. Path U. Pharmakol. 222, 173 - 175.

Habernann, $\sum$ and Reiz, G. (1965): Bichem J. 341, Cited by Bucherl W. and Buckley E. (1971): "Venomous animals and their venoms" Academic press. Vol. III. 61-93.

Assiut Vet. Med. J. Vol. 4 №. $8,1977$. 


\section{MOHAMED et al.}

\section{$-64-$}

Habermann, E and Zeumer, G (1971): Comparative studies of native and synthetic mellitins. Naunyn -Schmiedebergs Arch. pharmak. 270, 1 - 9 .

Hamed, H.Y.; Abd EI Aziz, F. T and lifohamed M. G (1973): Preliminary biochemical study on the soluble venom of the date wasp arientalis. Bulletin of faculty of science. 2, $199-205$.

Hamed, M.Y. and Hohamed M.G. (1975): Biological studies on the venom of date wasp (vespa orientalis) II. Effect of the venom on the oxygen consumption by isolated tissue clices. Assiut Med. Vet. J. 2, 85-89.

Heydenreich, H. (1957); Inaugural Bissertation, University of Wurzburg. Cited by Bucherl,W. and Buckley E.(1971). "Venomous animals and their venoms". Acadamic press. Vol. III. $61-93$.

Jaques, $R$ and Schachter, M. (1954): Presence of histamine; 5, hydroxytryptamine and potent, slow contracting substance in wasp venom, Brit. J. Pharmacol. 9, 53-58. Jaques,R. (1955): Vergleichende Fermentuntersuchungen über tierischen Giften (Cholinestrase "Zecithinase" Hyaluronidase) Helvit. Physiol. et Pharmacal. acta. 13, $113-120$.

Kellaway, C.H. and Trethewit, L.R. (1940): Liberation of adenyl compounds from perfused organ by cobra venom. Australian J. exper. Biol. Med. Sci. 18, 63 - 88.

Mohamed, A.H., Hamed, I..Y., Afifi, A.M., Effat, N.M. and Mohamed, M.G. (1972): Biological studies on the venom of Date wasp (Vespa orientalis). I Effect of the venom on anaethetized dogs. Egyptian. Vet. Med. J. $x x .223$.

Walter T.B. and Israel, H.S. (1965): General pathology. publisher Churchill J. A. London.

Assiut Vet. Med. J. Vol. 4 № 8 , 1977. 


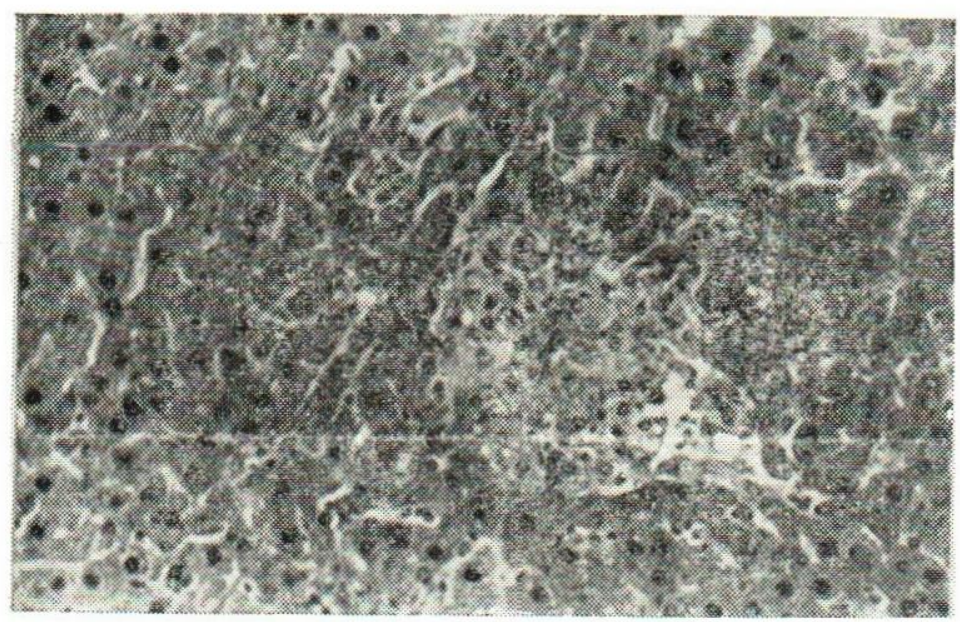

Figure [1]

One stings application for 30 second. Diffuse granular proteinous dystrophy and foci of cell lysis. H, E. $[: 0 \times 12.5]$.

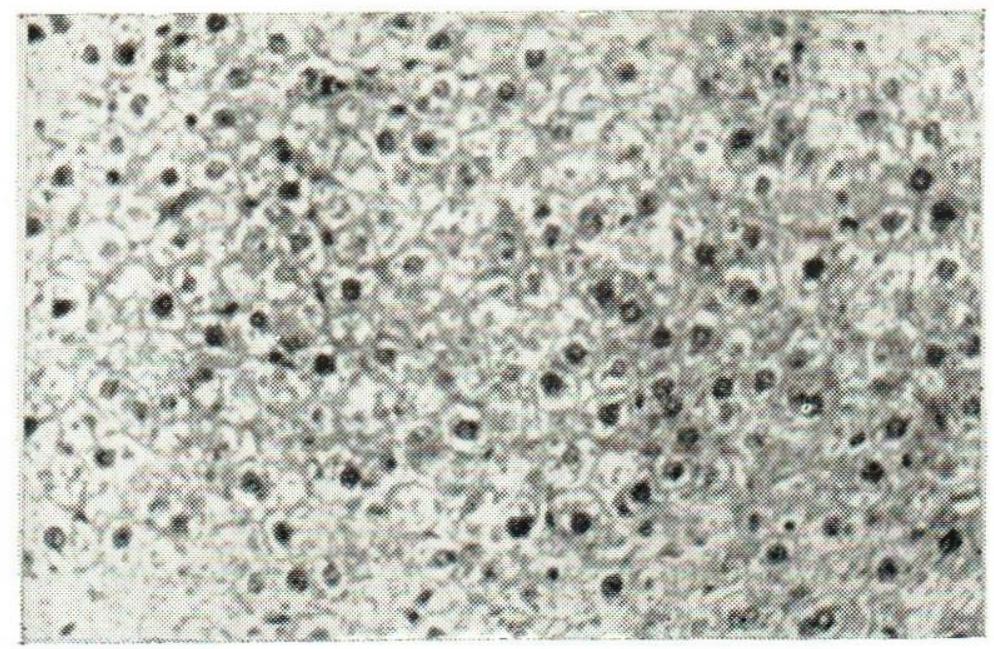

Figure [2]

Two stings application for 60 second. Diffuse and advanced hydropic dystrophy. H, E . $[10 \times 12.5]$. 


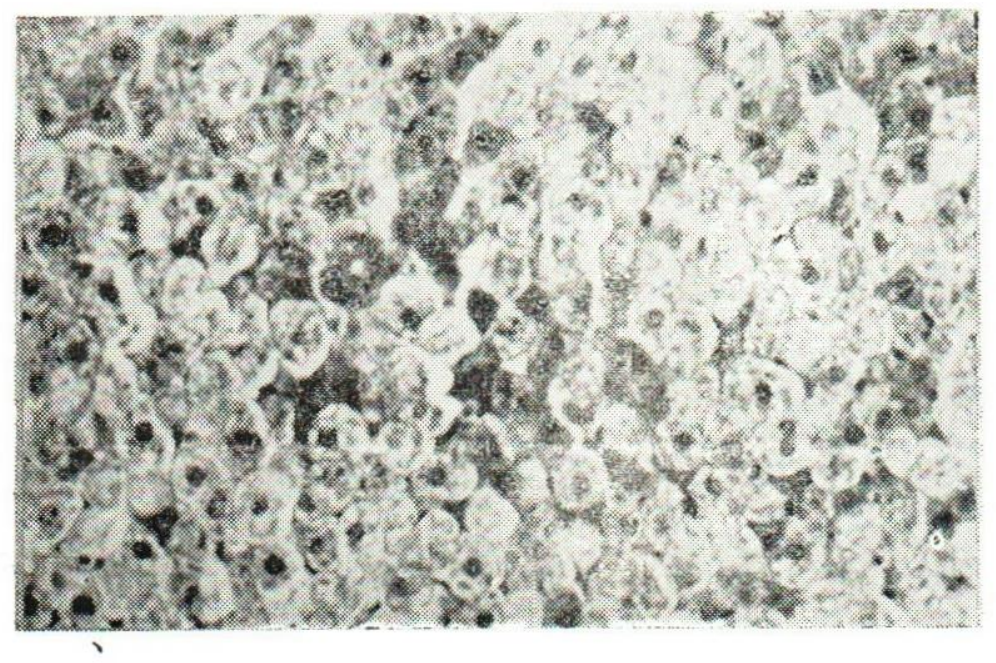

Figure [ 3 ]

Two stings application for 60 second. Few PAS + granules present in the cytoplasm of sporadic liver cells.

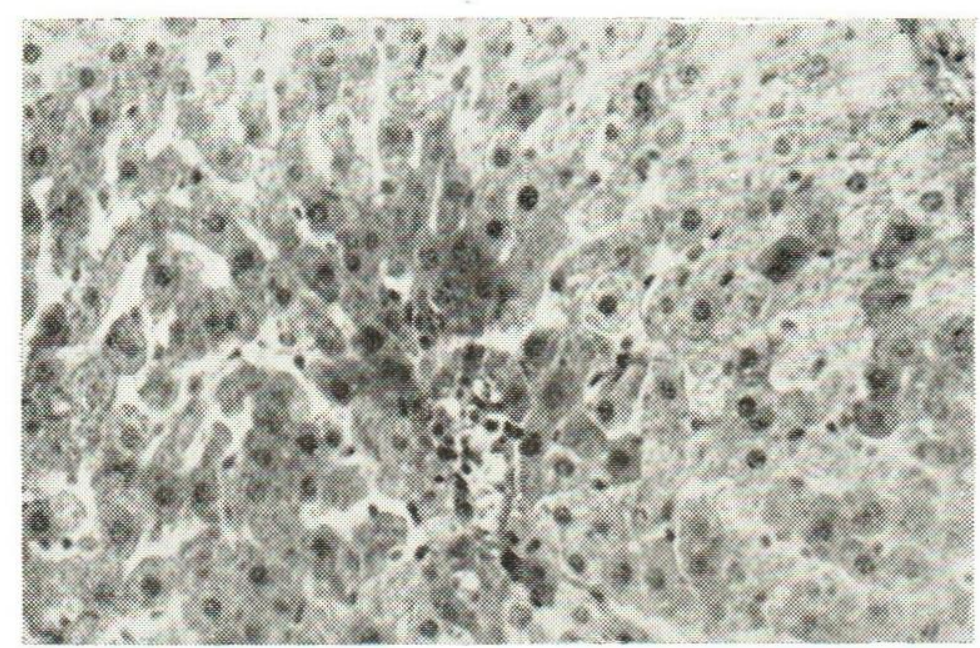

Figure [4]

Five stings application for 60 second. Zones of light swelling of the liver cells. $\mathrm{H}, \mathrm{E}$. [ $: 0 \times 12.5]$. 
$\div$ 


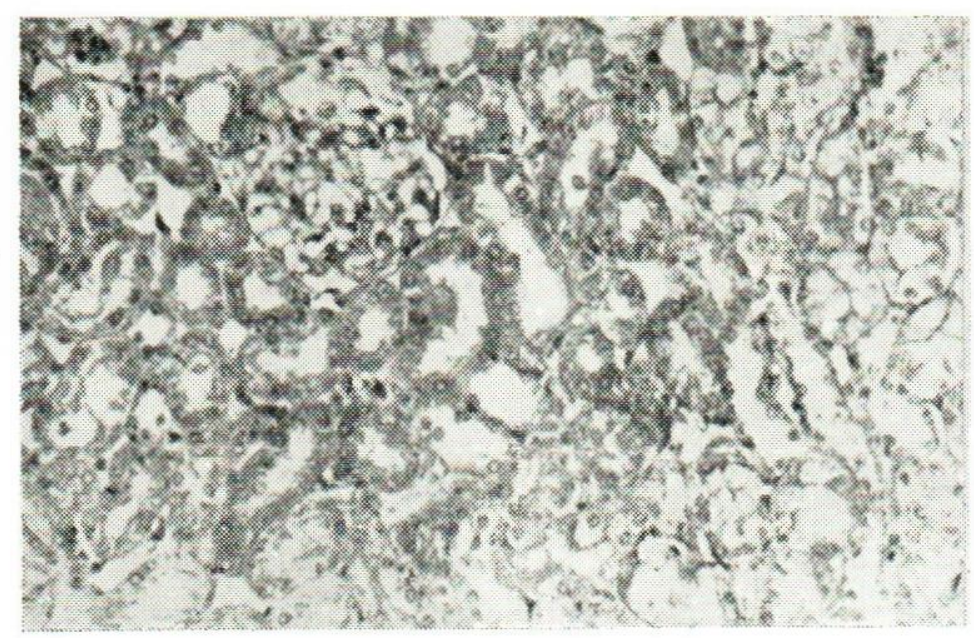

Figure [5]

One sting application for 30 second. Diffuse granular proteinous dystrophy. H, E. [ 0 x 12.5].

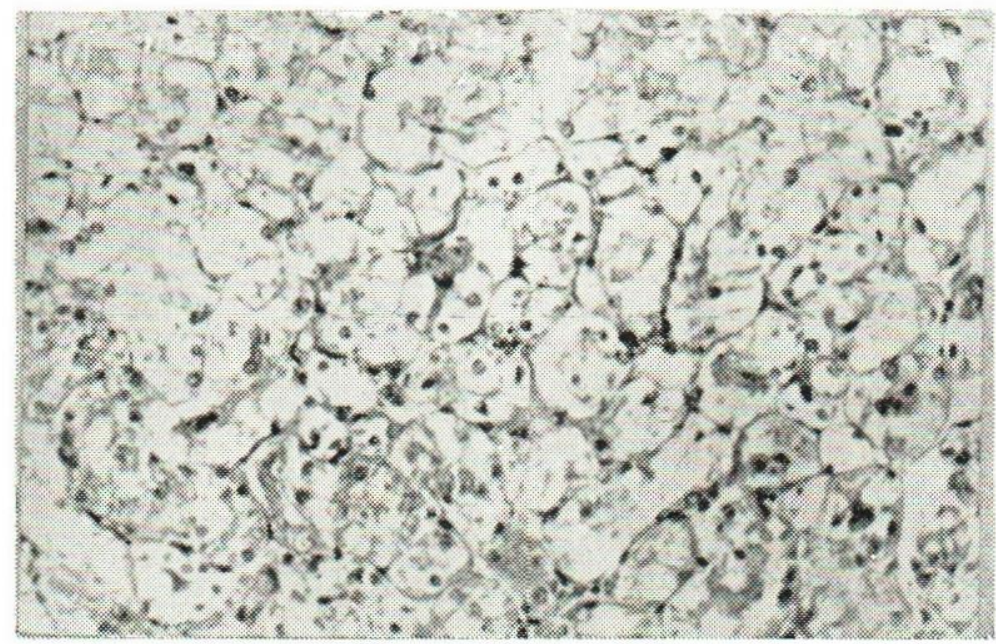

Figure [6]

Two stings application for 60 sccond. Diffuse hydropic dystrophy. H, E. [ $10 \times 12.5]$. 
7 